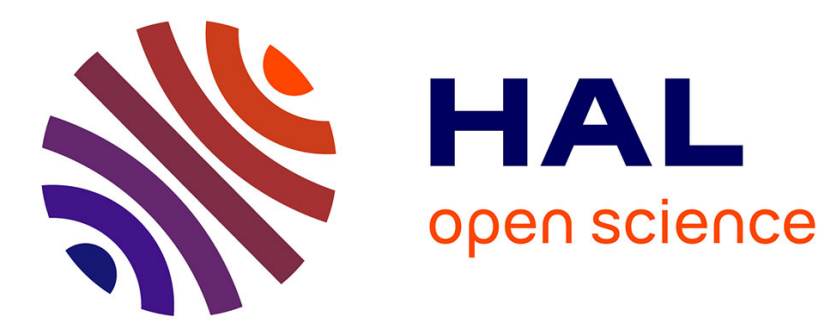

\title{
Fluids and melts in planetary interiors: From crust to core-mantle boundaries
}

\author{
Carmen Sanchez-Valle, Fabrice Gaillard, Sujoy Ghosh, Klaus Metzger
}

\section{To cite this version:}

Carmen Sanchez-Valle, Fabrice Gaillard, Sujoy Ghosh, Klaus Metzger. Fluids and melts in planetary interiors: From crust to core-mantle boundaries. Chemical Geology, 2015, 418, pp.1-5. 10.1016/j.chemgeo.2015.11.012 . insu-01234313

\section{HAL Id: insu-01234313 \\ https://hal-insu.archives-ouvertes.fr/insu-01234313}

Submitted on 26 Nov 2015

HAL is a multi-disciplinary open access archive for the deposit and dissemination of scientific research documents, whether they are published or not. The documents may come from teaching and research institutions in France or abroad, or from public or private research centers.
L'archive ouverte pluridisciplinaire HAL, est destinée au dépôt et à la diffusion de documents scientifiques de niveau recherche, publiés ou non, émanant des établissements d'enseignement et de recherche français ou étrangers, des laboratoires publics ou privés.

\section{(1) (1) $\$$}

Distributed under a Creative Commons Attribution - NonCommercial - NoDerivatives 44.0 


\section{Accepted Manuscript}

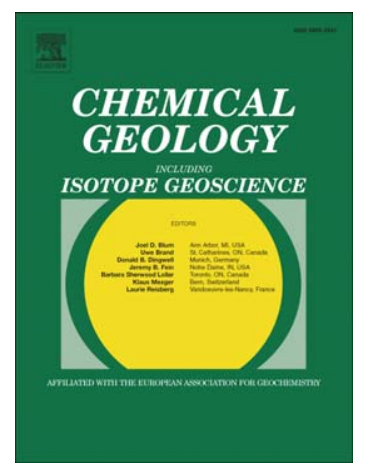

Fluids and melts in planetary interiors: From crust to core-mantle boundaries

Carmen Sanchez-Valle, Fabrice Gaillard, Sujoy Ghosh, Klaus Metzger

PII: $\quad$ S0009-2541(15)00489-1

DOI: $\quad$ doi: $10.1016 /$ j.chemgeo.2015.11.012

Reference: $\quad$ CHEMGE 17766

To appear in: $\quad$ Chemical Geology

Please cite this article as: Sanchez-Valle, Carmen, Gaillard, Fabrice, Ghosh, Sujoy, Metzger, Klaus, Fluids and melts in planetary interiors: From crust to core-mantle boundaries, Chemical Geology (2015), doi: 10.1016/j.chemgeo.2015.11.012

This is a PDF file of an unedited manuscript that has been accepted for publication. As a service to our customers we are providing this early version of the manuscript. The manuscript will undergo copyediting, typesetting, and review of the resulting proof before it is published in its final form. Please note that during the production process errors may be discovered which could affect the content, and all legal disclaimers that apply to the journal pertain. 


\title{
Editorial Special Issue Chemical Geology
}

\author{
"Fluids and melts in planetary interiors: from crust to core-mantle boundaries" \\ Carmen Sanchez-Valle ${ }^{1}$, Fabrice Gaillard ${ }^{2}$, Sujoy Ghosh ${ }^{3}$ and Klaus Metzger ${ }^{4}$ \\ ${ }^{1}$ Institute for Mineralogy, University of Muenster, 48149 Muenster, Germany \\ ${ }^{2}$ ISTO, Orleans, France \\ ${ }^{3}$ Department of Geology and Geophysics, Indian Institute of Technology Kharagpur, 721302 Kharagpur, India \\ ${ }^{4}$ Department of Geological Sciences, University of Bern, Bern, Switzerland
}

\section{SCOPE}

Aqueous fluids and melts (silicate, carbonate/carbonatites or metallic melts) are major vectors of mass and heat transfer in planetary interiors and play an important role in a variety of geochemical and geodynamical processes that shape the internal and surficial evolution of planetary systems. These processes occur over a broad range of pressure and temperatures that span from shallow crustal conditions (e.g., magma chamber processes, ore deposit formation) to the deep core-mantle boundaries (e.g., planetary differentiation), and they are strongly influenced by the physical, chemical and structural properties of aqueous fluids and melts at relevant pressure and temperature conditions. Over the last decade, major progress has been made in the determination of the properties of aqueous fluids and melts thanks to the development of advanced experimental and computational methods. The goal of this special issue is to highlight some of these advancements and to discuss new views and open questions related to mass transfer and melting in planetary interiors, from crustal conditions to core-mantle boundaries and from the atomic to the planetary scales.

The seventeen contributions of this volume are organized in 4 topical sections that include review papers providing an overview of the current state of knowledge in the field, and accompanied by research papers. Section I addresses the mechanisms of reintroduction of water into planetary interiors via subduction, a primordial process for the generation of fluid and melts at depth (Ohtani, 2015-this issue; 
Walter et al., 2015-this issue), and the role of slab-derived fluids on mass transfer from subducting slabs to the mantle wedge and arc magmatism (Jahn et al., 2015-this issue). Section II focuses on novel data on the properties of volatile-bearing silicate melts, with emphasis on (i) the solubility mechanisms and speciation of volatiles, $\mathrm{H}_{2} \mathrm{O}, \mathrm{CO}_{2}, \mathrm{Cl}$ and $\mathrm{S}$ (Lesne et al., 2015-this issue; Botcharnikov et al., 2015-this issue; Beermann et al., 2015-this issue) in silicate melts with potential applications on ore-forming processes and volcanic degassing, on (ii) the effect of volatiles on the physical properties (density, viscosity and electrical conductivity) (Bouhifd et al., 2015-this issue; Laumonier et al., 2015a-this issue; Robert et al., 2015-this issue) and the molecular structure (Vuilleumier et al., 2015-this issue; Morizet et al., 2015-this issue) of silicate melts, and on (iv) the timely topic of mixing/mingling of silicate melts and magmas in the crust (Laumonier et al., 2015b-this issue). Section III examines the effect of $\mathrm{CO}_{2}$ in melting at mantle depth (Hammouda and Keshav, 2015-this issue) and presents new models for the electrical conductivity of carbonated melts (Sifre et al., 2015-this issue), the solubility of $\mathrm{CO}_{2}$ in kimberlites (Moussallam et al., 2015this issue) and the thermodynamics of mixing between carbonate and silicate melts that rule mantle partial melting (Massuyeau et al., 2015-this issue). Finally, Section IV analyses the interplay between volatiles including carbon, hydrogen and sulfur in magmas and the redox state of the planetary interiors, and examines potential secular variations in these parameters through the ages of the Earth (Gaillard et al., 2015-this issue).

\section{WATER TRANSPORT INTO THE EARTH'S INTERIOR}

The reintroduction of water into the mantle via subduction, and its storage and global scale circulation have important implications for understanding chemical mass transfer and for the dynamics of the deep mantle (Regenauer-Lieb, 2006; Korenaga, 2011). Changes in the water storage capacity of the mantle with depth may drive melting in a variety of environments, including oceanic basalt sources, the mantle wedge above subducting plates and deeper regions above and below the transition zones (Hirschmann, 2006). 
Much effort has been put forth to elucidate the phase relations in hydrous subducted lithologies, to identify the major water carriers and to place quantitative constraints on the fluxes of water into the mantle (e.g., Ohtani et al., 2004; Iwamori et al., 2004; Kawamoto, 2006; Litasov and Ohtani, 2007). A series of minerals reactions in hydrous peridotite that stabilize high-pressure phases such as Phase A or phase E provide a path for water into the transition zone (Ohtani et al., 2004), where is further stored in wadsleyite and ringwoodite (Keppler and Bolfan-Casanova, 2006), hence creating a long-lived hydrogen reservoir in the solid Earth (Kawamoto et al., 1996; Ohtani et al., 2001). The recent discovery of hydrous ringwoodite inclusions in a super-deep diamond from Juina (Brazil) provides evidence for a hydrous transition zone, at least in the vicinity of subduction zones (Pearson et al., 2014), that is also supported by seismic tomography studies and electrical conductivity measurements (Koyama et al., 2006).

The water fluxes into the lower mantle are less well constrained. However, the detection of low seismic velocity and high attenuation anomalies atop of the lower mantle suggest melting, likely related to the dehydration of ultra-high pressure phases in the slab (Lawrence et al., 2006; Schmandt et al., 2014). Water transport beyond the transition zone is linked to the stability of phase $D\left(\mathrm{MgSi}_{2} \mathrm{H}_{2} \mathrm{O}_{6}\right)$ in peridotitic lithologies (Ghosh and Schmidt, 2014a; Pamato et al., 2015). The recently discovered of ultrahigh pressure phases such hydrous phase $\mathrm{H}, \mathrm{MgSiO}_{2}(\mathrm{OH})_{2}$ (Nishi et al., 2014), and its solid-solution with isostructural $\delta$-AlOOH (Ohira et al., 2014) suggest deep transport of water as cold slabs penetrate down to core-mantle-boundary (e.g., Fukao et al., 2001; Grand, 2002). In the review paper that opens this Special Issue, Ohtani (2015-this issue) provides an overview on potential water reservoirs in subducting slabs, the water storage capacity of the transition zone and the lower mantle, and the role of the solid-solutions between phase $\mathrm{H}$ and $\delta$-AlOOH in the rehydration of the lower mantle. The phase relations and stability of ultrahigh pressure hydrous phases are discussed by Walter et al. (2015-this issue) based on laser heated diamond anvil cell experiments in the systems $\mathrm{MgO}-\mathrm{SiO}_{2}-\mathrm{H}_{2} \mathrm{O}(\mathrm{MSH})$ and $\mathrm{MgO}-\mathrm{Al}_{2} \mathrm{O}_{3}-\mathrm{SiO}_{2}-\mathrm{H}_{2} \mathrm{O}(\mathrm{MASH})$, and show that an aluminous hydrous phase, either $\mathrm{D}$ or $\mathrm{H}$, will be stable through the lower mantle along a cold subduction geotherm. However, none of 
these phases appears to be stable along a lower mantle adiabat (Walter et al., 2015-this issue; Ohira et al., 2014), or as the temperature of the slab increases rapidly at the core-mantle boundary (Ohtani, 2015-this issue), and a hydrous silicate melt produced upon dehydration melting is likely the host for hydrogen in the lower mantle. In this scenario, and as the hydrous melt comes into contact with metallic iron form the Earth's core, hydrogen could be dissolved into the core as FeNi hydrides (Terasaki et al., 2012). It appears, however, that the amount of hydrogen needed to explain the density deficit in the Earth's core exceeds the amount plausibly supplied via subduction of hydrous components, thus indicating the presence of primordial hydrogen, or other light elements, in the core.

According to experimental studies (Schmidt and Poli, 1998; Poli and Schmidt, 2002) and numerical models (van Keken et al., 2011), only one third of the water stored in the slab is recycled into the deep Earth. Continuous dehydration/devolatilization reactions at shallow depths $(<230 \mathrm{~km})$ result in the release of pulses of fluids into the mantle wedge that trigger melting in the slab and the adjacent mantle wedge in the sub-arc region (Tatsumi, 1995; Kawamoto et al., 2013). Hydrous melting beneath the arc play a principal role in redistributing elements between different mantle reservoirs, and the slab-derived fluids are critical agents of mass transfer and mantle differentiation within the geochemical cycles. Together with water and other volatiles $(\mathrm{C}, \mathrm{N}, \mathrm{Cl}, \mathrm{B})$, fluid-mobile elements are leached during fluid-rock interactions and transported from the slab to the mantle wedge, and eventually recycled back into the surface by erupted magmas. The characteristic geochemical signature of arc magmas informs about the relative mobility of elements (Elliott, 2003) but only provides a partial picture of the complex fluid/melt-rock interaction processes in deep settings. Experimental studies that combine high-pressure methods and a range of advanced microanalytical techniques have been key to elucidate the chemistry and nature of slab-derived fluids, and the distribution of elements during fluid-rock interactions and melting at depth (e.g., Brenan et al., 1995; Keppler., 1996; Manning, 2004; Manning et al., 2010; Kessel et al., 2005; Spandler et al., 2007; Herman and 
Spandler, 2008; Bali et al., 2012; Kawamoto et al., 2012; Sanchez-Valle, 2013; Spandler and Pirard, 2013;

Tsay et al., 2014, and references therein). However, the atomic-scale mechanism that controls the solubility of minerals in high pressure fluids and the transport of chemical elements remains poorly constrained. Few direct observations of the speciation of geochemical tracer in slab-derived fluids at relevant pressure and temperature conditions are available as they require in situ experimental approaches to snapshot the structure of unquenchable phases (Sanchez-Valle, 2013). Alternatively, molecular dynamic simulations have become a powerful tool to model the structure of aqueous fluids and melts (e.g., Guillot and Sator, 2007; Mookherjee et al., 2008; Jahn and Schmidt, 2010; Jahn and Kowalski, 2014, and references therein), including the complexation of trace elements (van Sijl et al., 2009; 2010), in a wide range of pressuretemperature and compositions. In this issue, Jahn et al. (2015-this issue) report results from ab inito molecular dynamics simulations on the complexation of $\mathrm{Zr}$ and $\mathrm{Hf}$ in high pressure aqueous fluids (basic, neutral and acidic) at mantle conditions. The predicted XANES spectra are consistent with experimental studies (Wilke et al., 2012; Louvel et al., 2013), and together emphasize the key role of the chemistry of the fluid in the mobilization and transport of high-field strength elements (HFSE).

\section{VOLATILES AND SILICATE MELTS}

Volatiles (namely $\mathrm{H}_{2} \mathrm{O}, \mathrm{CO}_{2}, \mathrm{~S}$ and $\mathrm{Cl}$ ) dissolved in silicate melts have a dramatic effect on the outcome of magmatic processes inasmuch as they affect their physical and structural properties at crustal and mantle conditions. The effect of volatiles on the physical properties (density, viscosity and electrical conductivity) of silicate melts is addressed here in papers by Bouhidf et al. (2015-this issue), Robert et al. (2015-this issue) and Laumonier et al. (2015a-this issue). Water is not only the main volatile in silicate melts, but it also has a dramatic effect on melt viscosity and density due to its low molecular weight (e.g., Mysen and Richet, 2005; Giordano et al., 2008; Malfait et al., 2014a). Direct measurements of the density and viscosity of volatilebearing silicate melts at high pressure and temperature conditions remain challenging and the available data 
is scarce (Burnham and Davis, 1971; Matsukage et al., 2005; Sakamaki et al., 2006; Ghosh et al., 2007; Ardia et al., 2008; Malfait et al., 2014a; 2014b and references therein). Alternative, measurements on glass samples to above the glass transition temperature $\left(T_{g}\right)$ have provided an extensive database for these properties in geologically relevant volatile-bearing silicate liquids at room pressures (e.g., Dingwell, 1987; Ochs and Lange, 1999; Mysen and Richet, 2005; Giordano et al., 2004; 2008). In this issue, Bouhifd et al. (2015-this issue) apply an improved dilatometry method to extend the density dataset for water-bearing silicate melts and confirm that the partial molar volume of dissolved water in silicate melts is independent of the chemical composition of the end-member. This uniform volume of dissolved water in silicate melts will simplify the construction of general density model for $\mathrm{H}_{2} \mathrm{O}$-bearing magmas at high pressure and high temperature. Robert et al. (2015-this issue) addressed a major limitation on the development of thermodynamic and physical properties of multicomponent silicate melts relevant to natural system: the combined effect volatiles (water, $\mathrm{F}$ and $\mathrm{CO}_{2}$ ) on the viscosity (and heat capacity) of basaltic melt compositions relevant to calc-alkaline mafic magmas. The results indicate that the effect of $F$ on the viscosity of basaltic melts is much smaller than that of water, whereas the combined effect of both $\mathrm{H}_{2} \mathrm{O}$ and fluorine on the viscosity can be considered additive on wt\% basis. Interestingly, typical eruptive concentrations $\mathrm{CO}_{2}$ have a negligible effect on the viscosity of basaltic melts, at least in the presence of water. Laumonier et al. (2015a-this issue) report experiments to determine the effect of water and pressure on the electrical conductivity of dacitic melts and develop a predictive model that is applied to interpret the electrical signature of potential reservoirs in the crust and water-rich felsic melts in the mantle. They found a much stronger effect on the electrical conductivity of $\mathrm{H}_{2} \mathrm{O}$ in the high concentration ranges than what was suggested from previous measurements collected at low water content (Gaillard, 2004) in felsic melts. The authors conclude that electrical anomalies in the crust (e.g., Altiplano-Puna Volcanic Complex, Bolivia) and at the base of the mantle-wedge at subduction zones can be interpreted by the presence of silica-rich, 
hydrous, partially crystallized magma allowing the cycling of water to be tracked by geophysical methods in subduction regions.

The macroscopic melt properties discussed above are intimately linked to the molecular structure of the liquid that is in turn affected by the presence of dissolved volatiles. A prerequisite for a fundamental understanding and for the development of predictive models for these properties at crustal and mantle conditions is thus a detailed knowledge of the structure of the melt and the effect of dissolved volatiles as a function of pressure (e.g. Mysen and Richet, 2005). Structural studies on volatile-bearing silicate melts at high pressure and temperature remain experimentally challenging (e.g., Sanloup et al., 2013) and hence, analog glasses and theoretical approaches provide an alternative source of information. This two approaches are combined and contrasted in this Special Issue in the contributions of Vuilleumier et al. (2015-this issue) and Morizet et al. (2015-this issue). Applying atomistic simulations, Vuilleumier et al. (2015this issue) investigate the incorporation of $\mathrm{CO}_{2}$ in basalt and kimberlite melts and explore the solubility and speciation of $\mathrm{CO}_{2}$ and the structural changes in the silicate network at mantle pressures. The findings have important implications for the electrical conductivity of carbonated melts, and for miscibility of carbonate and silicate melts produced during incipient melting of $\mathrm{CO}_{2}$-rich source regions. Notably, magma rising along a mantle adiabat, the increasing structural differences between carbonatitic and silicate melt components will trigger phase separation that could play an important role in the genesis of $\mathrm{CO}_{2}$-rich volcanism. The structural predictions on high pressure melts obtained from first-principles molecular dynamic simulations are compared with the results from NMR studies on a simplified $\mathrm{CO}_{2}$-bearing basaltic composition in Morizet et al. (2015-this issue). The authors conclude that the aluminosilicate molecular structure is comparable in high temperature $\mathrm{CO}_{2}$-bearing basaltic melts and equivalent glasses, but find inconsistencies in the speciation of $\mathrm{CO}_{2}$ that would require additional in situ investigations to be resolved. 
The solubility of volatiles, $\mathrm{H}_{2} \mathrm{O}, \mathrm{S}$ and $\mathrm{Cl}$, in ore-forming magmas, and their partitioning between exsolved magmatic fluids and silicate melts at shallow crustal depths, are addressed in a series of experimental paper by Lesne et al. (2015-this issue), Botcharnikov et al. (2015-this issue) and Beermann et al. (2015-this issue). Lesne et al. (2015-this issue) propose a preliminary thermodynamic species-based model for the solubility of sulfur in hydrous basaltic melts as a function of sulfur fugacity, $f S_{2}$ calibrated on new experimental data obtained at $1200{ }^{\circ} \mathrm{C}$ and from 200 to $250 \mathrm{MPa}$, under oxidizing conditions. The model shows a minimum in S-solubility around the NNO-buffer that is temperature dependent, and a shift of the $\mathrm{S}^{6+} / \mathrm{S}^{2-}$ equilibrium in the melt with $\mathrm{fO}_{2}$ as a function of $f S_{2}$. Most importantly, the model suggests that significant amount of sulfur may be present in the gas phase (in addition to $\mathrm{H}_{2} \mathrm{O}$ and $\mathrm{CO}_{2}$ ) during volcanic degassing. Botcharnikov et al. (2015-this issue) investigate the effect of pressure on the solubility of intermediate melts and the partitioning of $\mathrm{H}_{2} \mathrm{O}$ and $\mathrm{Cl}$ into exolved fluids at $1200{ }^{\circ} \mathrm{C}$, from 50 to $500 \mathrm{MPa}$, and conclude that fluid-melt partitioning of $\mathrm{Cl}$ is controlled by the fluid mixing properties and display a pronounced minimum at $200 \mathrm{MPa}$. The positive correlation between the $\mathrm{Cl}$ partition coefficients and the $\mathrm{SiO}_{2}$ content in the melt at a given pressure indicate that $\mathrm{Cl}$ can degas more efficiently from felsic than from mafic magmas. Similarly, Beermann et al. (2015-this issue) report on the partitioning of sulfur and chlorine between aqueous fluids and basaltic melts at $1050^{\circ} \mathrm{C}, 100$ and $200 \mathrm{MPa}$, at oxidized to moderately oxidized conditions, and link the results to field observations of the eruptive activity of Mt. Etna. It is shown that the partitioning that $\mathrm{S}$ and $\mathrm{Cl}$ between basalts and aqueous fluids is mostly non-ideal and that $\mathrm{Cl}$ increases the solubility of $\mathrm{S}$ in the fluid at oxidizing conditions. The experimentally derived $\mathrm{S} / \mathrm{Cl}$ ratios in fluids and melts compare well with records from the 2001-2003, episodes of passive degassing and or during mild strombolian activity, and contribute to clarify the behavior of volatiles during magmatic eruptions.

Finally, magma interaction processes in magma chamber and volcanic conduits are examined by Laumonier et al. (2015b-this issue) presenting the first dynamic mixing experiments between hydrous 
magmas, and discussing the implication for reservoir replenishment. According to the results, the mixing of hydrous magmas occurs at $\sim 170^{\circ} \mathrm{C}$ lower than observed for the dry counterparts, and the mixing/mingling appears plausible at crystal fractions below 50 vol.\%, while mingling may be plausible at crystal fractions higher than 50 vol.\% at the high strain rates that characterize volcanic conduits and magmatic reservoirs .

\section{DEEP CARBON AND CARBONATITE MELTS}

More than thirty years ago, a series of key papers were published on the topic of deep mantle carbon, dealing with the petrological, geochemical and geophysical consequences of its cycling through the various Earth's envelops. Seminal papers have revealed that in the presence of $\mathrm{CO}_{2}$, mantle melting is possible in the most of the upper mantle, while volatile-free mantle melting occurs essentially at depths shallower than 50 km (Green and Liebermann, 1976; Wallace and Green, 1989). Over the last decade, this topic has regained interest, partly due to the need to better reconstructing paleo-atmospheric $\mathrm{CO}_{2}$ contents and its role in global geodynamics, which in turn requires better knowledge of this other -deep- carbon cycle which influences the distribution of carbon in the Earth's interior (Hauri et al., 1993; Presnall and Gudfinnsson, 2005; Hammouda, 2004; Dasgupta and Hirschmann, 2006; lacono-Marziano et al., 2009;Ghosh et al., 2009; Rohrbach and Schmidt, 2011; Stagno et al., 2013; Sifré et al., 2014). Deep $\mathrm{CO}_{2}$-induced melting is a discovery that has critically changed our visualization of the Earth's mantle, which must be a two-phase system (solid+liquid) down to depths where our previous models postulated a single solid-type behavior. The implications of these findings for the broad scale geochemical and geodynamic evolution of the mantle are dramatic and several papers in this special issue pave the way for a better understanding of these processes. Here, are presented papers addressing the poorly known molecular structure (Vuillemier et al., 2015-this issue; Morizet et al., 2015-this issue, see section 3 for details), physical and chemical properties (Massuyeau et al., 2015-this issue; Moussallam et al., 2015-this issue; Sifré et al., 2015-this issue) of $\mathrm{CO}_{2}$-rich melts and they are accompanied by Hammouda and Keshav (2015-this issue) reviewing the last 40 years of 
(experimental) literature on the petrology of mantle melting in presence of $\mathrm{CO}_{2} \cdot \mathrm{CO}_{2}$-induced melting has been named incipient melting since small amounts of carbon are expected to prevail at mantle depth. The identified P-T boundary of incipient melting being discussed by Hammouda and Keshav (2015, this volume), have the peculiarities of being almost temperature independent: (i) the ledge, delineating the upper stability field of incipient melts, defines a reaction between $\mathrm{CO}_{2}$-rich melts and mantle minerals producing a $\mathrm{CO}_{2}$-rich vapor and clinopyroxene occurring in the depth range 50-70 km (Wallace and Green, 1989); (ii) redox melting, delineating the lower stability field of incipient melts, defines a reaction between $\mathrm{CO}_{2}$-rich melts and garnet producing diamonds at depth evaluated between 120 to $350 \mathrm{~km}$ depending on the availability of oxygen in the surrounding mantle (Rohrbach and Schmidt, 2011; Stagno et al., 2013). Both reactions (i and ii) are reversible and bracket the mantle domain where incipient melting prevails in the convecting upper mantle. Hammouda and Keshav (2015-this issue) furthermore discuss the special case of carbonatites. The other peculiarity of incipient melting is the melt composition that ranges from silica-poor carbonatites to $\mathrm{CO}_{2}$-rich silicate melts (Gudfinnson and Presnall, 2005; Dasgupta et al., 2013; Ghosh et al., 2014b). Massuyeau et al. (2015-this issue) provides the first thermodynamics modelling of carbonated silicate melts. By quantitatively capturing the silica activity, a probe of the energetic costs of the dissolution of silica in carbonate melts, Massuyeau et al. (2015-this issue) define the changes in incipient melt compositions that are in equilibrium with mantle minerals in the vast P-T domain of the upper mantle. This model allows us to capture the narrow P-T conditions where mantle melts shift in composition from carbonatites (below 5 GPa pressures) to kimberlites (above $5 \mathrm{GPa}$ ) to basanites at about 2-3 GPa. Kimberlites are addressed by Moussallam et al. (2015-this issue) defining the first solubility law for $\mathrm{CO}_{2}$ for these enigmatic melts. This achievement is permitted thanks to the possibility of quenching crystal-free glasses having the chemical composition of what we could name a synthetic analogue of kimberlite melts. These melts contain $20 \mathrm{wt} \%$ $\mathrm{SiO}_{2}$ and a similar content of $\mathrm{CO}_{2}$, all dissolved as carbonates at the moderate pressure of $200 \mathrm{MPa}$. The implication is that kimberlite melts can reach very shallow depth, about 3-5 km below the surface, with 
massive amount of $\mathrm{CO}_{2}$ being still dissolved. For these special melts, most of the $\mathrm{CO}_{2}$ degassing would then occur very shallow in the upper crust, which is the opposite of what is expected from basalts. Finally, Sifré et al. (2015-this issue) provide measurements of the electrical conductivity of carbonatite melts at upper mantle conditions. This work extends previous measurements at low pressure (Gaillard et al., 2008), establishes a clear link with other transport properties such as diffusion and viscosity (Kono et al., 2013), and proposes quantitative interpretation of the rejuvenation process imaged by electromagnetic survey below the South American craton (Bologna et al., 2012); a process that may be attributed to small amount of carbonatite melts pervasively wetting the thick lithospheric roots.

\section{A PLANETARY PERSPECTIVE ON VOLATILES, REDOX, AND MAGMAS}

Here, we conclude that volatiles such as hydrogen, carbon, sulfur, halogens are all present in the deep Earth and that we need to go towards multicomponent volatile systems facing the complexity of the Earth. All this volatile geodynamics must additionally integrate the redox parameters, a gauge of the availability of oxygen in the deep Earth, which impacts on volatile speciation. Changes in the redox state in the deep Earth can trigger melting, making carbon immobile (diamonds) or mobile $\left(\mathrm{CO}_{2}\right.$-rich melts), can enhance by a factor of 10 the solubility of sulfur in basalts, or can impact of the solubility of $\mathrm{H}_{2} \mathrm{O}$ in nominally anhydrous minerals or favor $\mathrm{CH}_{4}$ as a stable component carrying together deep hydrogen and deep carbon. Gaillard et al. (2015this issue) summarize our current knowledge of the redox state of the Earth's mantle and how this is sampled by mantle melts such as basalts. The oxidation state of the Earth's mantle seems to vary weakly with geodynamics yielding indistinguishable redox state for primary melts produced at ridges, intraplate and subduction regions. Furthermore, magma production back to the Archaean seems to display the same redox state as modern magma. Gaillard et al. (2015-this issue) conclude that our conceptual pictures on the parameters that control the redox state of deep rocks and melts (i.e., degree of mantle melting, metasomatism by volatile-rich melts and depth of melting) mostly argue against the observations of 
constancy in the redox state of basalts and of their mantle sources. Development of a new generation of oxygen-barometers involving iron or other redox-sensitive elements in silicate phases, as well as volatile species (C-H-S), with a significant reduction of uncertainties appear mandatory at this stage of knowledge.

\section{ACKNOWLEDGMENTS}

This special issue is derived from a session organized at Fall AGU Meeting 2013 sponsored by the "Mineral and Rock Physics". We thank all the authors that have contributed to this special issue. We are deeply grateful to many referees for assisting in the evaluation of the manuscript and for constructive criticism that helped to improve the quality of the contributions.

\section{REFERENCES}

Ardia, P., Giordano, D., Schmidt, M.W., 2009. A model for the viscosity of rhyolite as a function of $\mathrm{H}_{2} \mathrm{O}-$ content and pressure: A calibration based on centrifuge piston cylinder experiments

Bali, E., Keppler, H., Audetat, A., 2012. The mobility of $W$ and Mo in subduction zone fluids and the Mo-W-Th-U systematics of island arc magmas. Earth Planet. Sci. Lett. 351, 195-207.

Bologna, M.S., Padilha, A.L., Vitorello, I., 2005. Geoelectric crustal structures off the SW border of the Sao Francisco craton, central Brazil, as inferred from a magnetotelluric survey. Geophys. J. Int. 162, 357-370.

Brenan, J.M., Shaw, H.F., Ryerson, F.J., Phinney, D.L. ,1995. Experimental determination of trace element partitioning between pargasite and a synthetic andesitic melt. Earth Planet. Sci. Lett. 135, 1-11.

Burnham, C. W., Davis, N. F., 1971. Role of $\mathrm{H}_{2} \mathrm{O}$ in silicate melts. 1. P-V-T relations in the system $\mathrm{NaAlSi}_{3} \mathrm{O}_{8}-\mathrm{H}_{2} \mathrm{O}$ to 10 kilobars and $1000^{\circ} \mathrm{C}$. Am. J. Sci. 270, 54-79.

Dasgupta, R., Hirschmann, M.M., 2006. Melting in the Earth's deep upper mantle caused by carbon dioxide. Nature 440, 659-662.

Dasgupta, R., Mallik, A., Tsuno, K., Withers, A.C., Hirth, G., Hirschmann, M.M., 2013. Carbon-dioxide-rich silicate melt in the Earth's upper mantle. Nature 493, 211-215.

Dingwell, D.B., 1987. Melt viscosities in the system NaAlSi $\mathrm{O}_{8}-\mathrm{H}_{2} \mathrm{O}-\mathrm{F}_{2} \mathrm{O}_{-1}$ In: Mysen, B.O. (Ed.), Magmatic Processes: Physicochemical Principles. The Geochemical Society, 423-431. 
Elliott, T. R., 2003. Tracers of the slab. In Inside the Subduction Factory, edited by J. Eiler, 23-45, Geophysical Monograph Series, Washington, D.C.

Fukao, Y., Widiyantoro, S., Obayashi, M., 2001. Stagnant slabs in the upper and lower mantle transition region. Rev. Geophys. 39, 291-323.

Gaillard F., 2004. Laboratory measurements of electrical conductivity of hydrous and dry silicic melt under pressure. Earth Planet. Scie. Lett., 218, 215-228.

Gaillard, F., Malki, M., lacono-Marziano, G., Pichavant, M., Scaillet, B., 2008. Carbonatite melts and electrical conductivity in the asthenosphere. Science 322, $1363-1365$.

Ghosh, S., Schmidt, M.W., 2014a. Melting of phase D in the lower mantle and implications for recycling and storage of $\mathrm{H}_{2} \mathrm{O}$ in the deep mantle. Geochim. Cosmochim. Acta 145, 72-88.

Ghosh, S., Litasov, K., Ohtani, E., 2014b. Phase relations and melting of carbonated peridotite from 10 to 20 GPa: metasomatised $\mathrm{CO}_{2}$ and alkali-rich silicate melts in the deep mantle. Contrib. Mineral. Petrol., 167, 1-23.

Ghosh, S., Ohtani, E., Litasov, K., Suzuki, A., Sakamaki, T., 2007. Stability of carbonated magmas at the base of the Earth's upper mantle. Geophys. Res. Lett. 34, L22312.

Ghosh, S., Ohtani, E., Litasov, K.D., Terasaki, H., 2009. Solidus of carbonated peridotite from 10 to $20 \mathrm{GPa}$ and origin of magnesiocarbonatite melt in the Earth's deep mantle. Chem. Geol. 262, 17-28.

Giordano, D., Romano, C., Dingwell, D.B., Poe, B., Behrens, H., 2004. The combined efects of water and fluorine on the viscosity of silicic magmas. Geochim. Cosmochim. Acta 68, 5159-5168.

Giordano, D., Russell, J.K., Dingwell, D.B., 2008. Viscosity of magmatic liquids: a model. Earth Planet. Sci. Lett. 271, 123134.

Grand, S.P., 2002. Mantle shear-wave tomography and the fate of subducted slabs. Philos. Trans. R. Soc. A 360, 24752491.

Green, D. H., Liebermann, R. C., 1976. Phase equilibria and elastic properties of a pyrolite model for the oceanic upper mantle. Tectonophysics 32, 61-92.

Gudfinnsson, G.H., Presnall, D.C., 2005. Continuous gradations among primary carbonatitic, kimberlitic, melilititic, basaltic, picritic, and komatiitic melts in equilibrium with garnet lherzolite at 3-8 GPa. J Petrol. 46, 1645-1659.

Guillot B. and Sator N., 2007. A computer simulation study of natural silicate melts. Part II: High pressure properties. Geochim. Cosmochim. Acta 71, 4538-4556.

Hammouda, T., 2003. High-pressure melting of carbonated eclogite and experimental constraints on carbon recycling and storage in the mantle. Earth Planet. Sci. Lett. 214, 357-368.

Hauri, E.H., Shimizu, N., Dieu, J.J., Hart, S.R., 1993. Evidence for hotspot-related carbonatite metasomatism in the oceanic upper mantle. Nature 365, 221-227.

Hermann, J., Spandler, C.J., 2008. Sediment melts at sub-arc depths: An experimental study. J. Petrol. 49(4), 717-740.

Hirschmann, M.M., 2006. Water, Melting, and the Deep Earth $\mathrm{H}_{2} \mathrm{O}$ Cycle. Annu. Rev. Earth Planet. Sci. 34,629 - 653. 
lacono-Marziano G., Gaillard, F., Scaillet B., Pichavant M., Chiodini G., 2009. The role of non-mantle CO2 in the dynamic of volcano degassing: the Mt.Vesuvius exemple. Geology 37, 319-322.

Iwamori, H., 2004. Phase relations of peridotites under $\mathrm{H}_{2} \mathrm{O}$-saturated conditions and ability of subducting plates for transportation of $\mathrm{H}_{2} \mathrm{O}$. Earth Planet. Sci. Lett. 227, 57-71.

Jahn, S., Schmidt, C., 2010. Speciation in aqueous $\mathrm{MgSO}_{4}$ fluids at high pressures and high temperatures from ab initio molecular dynamics and Raman spectroscopy. J. Phys. Chem. B 114, 15565-15572.

Jahn, S., Kowalski, P.M., 2014. Theoretical Approaches to Structure and Spectroscopy of Earth Materials. In: Spectroscopic methods. Rev. Mineral. Geochem. 78, 691-743.

Kawamoto, T., Kanzaki, M., Mibe, K, Matsukage, K.N., Ono, S., 2012. Separation of supercritical slab-fluids to form aqueous fluid and melt components in subduction zone magmatism. Proc. Natl. Acad. Sci. USA 109, 1869518700.

Kawamoto, T., Mibe, K., Bureau, H., Reguer, S., Mocuta, C., Kubsky, S., Thiaudiere, D., Ono, S., Kogiso, T., 2014. Largeion lithophile elements delivered by saline fluids to the sub-arc mantle. Earth Planets Space 66, 61-67.

Kawamoto, T., 2006. Hydrous Phases and Water Transport in the Subducting Slab. In Water in nominally anhydrous minerals. Rev. Mineral. Geochem. 62, 273-290.

Kawamoto, T., Hervig, R.L., Holloway, J.R., 1996. Experimental evidence for a hydrous transition zone in the early Earth's mantle. Earth Planet. Sci. Lett. 142, 587-592.

Kawamoto, T., Yoshikawa, M., Kumagai, Y., Mirabueno, M.H.T., Okuno, M., Kobayashi, T., 2013. Mantle wedge infiltrated with saline fluids from dehydration and decarbonation of subducting slab. Proc. Natl. Acad. Sci. USA $110,9663-9668$.

Keppler, H., 1996. Constraints from partitioning experiments on the composition of subduction-zone fluids. Nature 380, 237-240.

Keppler, H., Bolfan-Casanova, N., 2006. Thermodynamics of Water Solubility and Partitioning. In: Water in nominally anhydrous silicates. Rev. Mineral. Geochem. 62, 193 - 230.

Kessel, R., Schmidt, M.W., Ulmer, P., Pettke, T., 2005. Trace element signature of subduction-zone fluids, melts and supercritical liquids at 120-180 km depth. Nature 437, 724-727.

Kono, Y., Kenney-Benson, C., Hummer, D., et al., 2014a. Ultralow Viscosity of Carbonate Melts at High Pressures. Nat. Commun., 5, 5091.

Korenaga, Y., 2011. Thermal evolution with a hydrating mantle and the initiation of plate tectonics in the early Earth. J. Geophys. Res. 116, doi: 10.1029/2011JB008410

Koyama, T., Shimizu, H., Utada, H., Ichiki, M., Ohtani, E., Hae, R., 2006. Water content in the mantle transition zone beneath the North Pacific derived from the electrical conductivity anomaly. Geophysical Monograph Series 168, American Geophysical Union, 171-179. 
Lawrence, J.F., Wysession, M.E., 2006. Seismic Evidence for Subduction-Transported Water in the Lower Mantle. Geophys Monogr Ser, Eds.: Jacobsen, S.D., Van Der Lee, S., American Geophysical Union, Washington, D.C. 168, 251-261.

Litasov, K.D., Ohtani, E., 2007. Effect of water on the phase relations in Earth's mantle and deep water cycle. GSA Special Papers, 421, 115-156.

Louvel, M., Sanchez-Valle, C., Malfait, W.J., Tesmale, D., Hazemann, J.-L. (2013) Zr 463 complexation in high pressure fluids and silicate melts and implication for the mobilization of HFSE in subduction zones. Geochim. Cosmochim. Acta, 104, 281-299.

Malfait, W.M., Seifert, R., Petitgirard, S., Mezouar, M., Ota, T., Sanchez-Valle, C., 2014b. The density of andesitic melts and the compressibility of dissolved water in silicate melts at crustal and upper mantle conditions. Earth Planet. Sci. Lett. 393, 31-38.

Malfait, W.M., Seifert, R., Petitgirard, S., Perrillat, J.-P., Mezouar, M., Ota, T., Nakamura, E., Lerch, P., Sanchez-Valle, C., 2014a. Supervolcano eruptions driven by melt buoyancy in large silicic magma chambers. Nat. Geoscien. 7, 122125.

Manning, C.E., 2004. The chemistry of subduction-zone fluids. Earth Planet. Sci. Lett. 223(1-2), 1-16.

Manning, C. E., Antignano, A., Lin, H. A., 2010. Premelting polymerization of crustal and mantle fluids, as indicated by the solubility of albite + paragonite + quartz in $\mathrm{H}_{2} \mathrm{O}$ at $1 \mathrm{GPa}$ and $350-620^{\circ} \mathrm{C}$. Earth Planet. Sci. Lett. 292, 325-336.

Matsukage, K.N., Jing, Z., Karato, S.I., 2005. Density of hydrous silicate melt at the conditions of Earth's deep upper mantle. Nature 438, 488-491.

Mookherjee, M., Stixrude, L., Karki, B., 2008. Hydrous silicate melt at high pressure. Nature 452, 983-986.

Mysen, B. O., Richet, P., 2005. Silicate glasses and melts: properties and structure, Elsevier, Amsterdam.

Nishi, M., Irifune, T., Tsuchiya, J., Tange, Y., Nishihara, Y., Fujino, K., Higo, Y., 2014. Stability of hydrous silicate at high pressures and water transport to the deep lower mantle. Nat. Geoscien. 7, 224-227.

Ochs, F.A., Lange, R.A., 1999. The density of hydous magmatic liquids. Science 283, 1314-1317.

Ohira, I., Ohtani, E., Sakai, T., Miyahara, M., Hirao, N., Ohishi, Y., and Nishijama, M., 2014. Stability of a hydrous $\delta$ phase, $\mathrm{AlOOH}-\mathrm{MgSiO}_{2}(\mathrm{OH})_{2}$, and a mechanism for water transport into the base of lower mantle. Earth Planet. Sci. Lett. 401, 12-17.

Ohtani, E., Toma, M., Litasov, K., Kubo, T., Suzuki, A., 2001. Stability of dense hydrous magnesium silicate phases and water storage capacity in the transition zone and lower mantle. Phys. Earth Planet. Inter. 124, 105-117.

Ohtani, E., Litasov, K., Hosoya, T., Kubo, T., Kondo, T., 2004. Water transport into the deep mantle and formation of a hydrous transition zone. Phys. Earth and Planet. Int., 143, 255-269.

Pamato, M.G., Myhill, R., Boffa-Ballaran, T., Frost, D.J., Heidelbach, F., Miyajima, N., 2015. Lower-mantle water reservoir implied by the extreme stability of a hydrous aluminosilicate. Nature Geoscien. 8, 75-79. 
Pearson, D.G., Brenker, F.E., Nestola, F., McNeill, J., Nasdala, L., Hutchison, M.T., Matveev, S., Mather, K., Silversmit, G., Schmitz, S., Vekemans, B., and Vincze, L., 2014. Hydrous mantle transition zone indicated by ringwoodite included within diamond. Nature, 507, 221-224.

Poli, S., Schmidt, M.W., 2002. Petrology of subducted slabs. Annu. Rev. Earth Planet. Sci., 30, 207-235.

Presnall, D.C., Gudfinnsson, G.H., 2005. Carbonate-rich melts in the oceanic low velocity zone and deep mantle. In: Foulger, G.R.,Natland, J., Presnall,D.C., Anderson,D.L. (Eds.), Plates, Plumes, and Paradigms. Geol. Society of America, Special Papers 388, 207-216.

Regenauer-Lieb, K., 2006. Water and geodynamics. In: Water in nominally anhydrous minerals. Rev. Mineral. Geochem. $62,451-474$

Rohrbach, A., Schmidt, M.W., 2011. Redox freezing and melting in the Earth's deep mantle resulting from carbon-iron redox coupling. Nature 472, 209-212.

Sakamaki, T., Suzuki, A., Ohtani, E., 2006. Stability of hydrous melt at the base of the Earth's upper mantle. Nature 439, 192-194.

Sanchez-Valle, C., 2013. Structure and thermodynamics of subduction zone fluids from spectroscopic studies. In: Thermodynamics of geothermal fluids. Rev. Mineral. Geochem. 76, 265-309.

Sanloup, C., Drewitt, J.W.E., Konopkova, Z., Dalladay-Simpson, P., Moroton, D.M., Rai, N., van Westrenen, W., Morgenroth, W., 2003. Structural change in molten basalts at deep mantle conditions. Nature 503, $104-107$.

Schmandt, B., Jacobsen, S.D., Becker, T.W., Liu, Z., Dueker, K. G., 2014. Dehydration melting at the top of the lower mantle. Science 344, 1265-1268.

Schmidt, M.W., Poli, S., 1998. Experimentally based water budgets for dehydrating slabs and consequences for arc magma generation. Earth Planet. Sci. Lett. 163, 361-379.

Sifré, D., Gardés, E., Massuyeau, M., Hashim, L., Hier-Majumder, S., Gaillard, F., 2014. Electrical conductivity during incipient melting in the oceanic low-velocity zone. Nature 509, 81-85.

Spandler, C., Mavrogenes, J., Hermann, J., 2007. Experimental constraints on element mobility from subducted sediments using high-P synthetic fluid/melt inclusions. Chem. Geol. 239, 228-249.

Spandler, C., Pirard, C., 2013. Element recycling from subducting slabs to arc crust: A review. Lithos 170, $208-223$.

Stagno, V., Ojwang, D.O., McCammon, C.A., Frost, D.J., 2013. The oxidation state of the mantle and the extraction of carbon from Earth's interior. Nature 493, 84-88.

Tatsumi, Y., Eggins, S., 1995. Subduction Zone Magmatism (Blackwell, Oxford).

Terasaki, H., Ohtani, E., Sakai, T., Kamada, S., Asanuma, H., Shibazaki, Y., 2012. Stability of Fe-Ni hydride after the reaction between Fe-Ni alloy and hydrous phase $(\delta-\mathrm{AlOOH})$ up to $1.2 \mathrm{Mbar}$ : Possibility of $\mathrm{H}$ contribution to the core density deficit. Phys. Earth Planet. Inter. 194-195, 18-24.

Tsay, A., Zajacz, Z., Sanchez-Valle, C., 2014. Efficient mobilization and fractionation of rare earth elements by aqueous fluids upon slab dehydration. Earth Planet. Sci. Lett. 398, 101-112. 
van Keken, P.E., Hacker, B.R., Syracuse, E.M., and Abers, G.A., 2011. Subduction factory: 4. Depth-dependent flux of $\mathrm{H}_{2} \mathrm{O}$ from subducting slabs worldwide. Journal Geophysical Research, 116, B01401.

van Sijl, J., Allan, N.L. Davies, G.R., van Westrenen, W., 2009. Molecular modelling of rare earth element complexation in subduction zone fluids. Geochim. Cosmochim. Acta 73, 3934-3947.

van Sijl, J., Allan, N. L., Davies, G. R., van Westrenen, W., 2010. Titanium in subduction zone fluids: First insights from ab initio molecular metadynamics simulations. Geochim. Cosmochim. Acta 74, 2797-2810.

Wallace, M.E., Green, D.H., 1988. An experimental determination of primary carbonatite magma composition. Nature $335,343-346$.

Wang, D., Mookherjee, M., Xu,Y., Karato, S.I., 2006. The effect of water on the electrical conductivity of olivine. Nature $443,977-980$.

Wilke, M., Schmidt, C., Dubrail, J., Appel, K., Borchert, M., Kvashnina, K., Manning, C. E., 2012. Zircon solubility and zirconium complexation in $\mathrm{H}_{2} \mathrm{O}+\mathrm{Na}_{2} \mathrm{O}+\mathrm{SiO}_{2} \pm \mathrm{Al}_{2} \mathrm{O}_{3}$ fluids at high pressure and temperature. Earth Planet. Sci. Lett. 349-350, 15-25. 